\title{
当日ブリーフレポート方式授業導入の試みによる 教育手法の効果と理学療法学生の特性の検討
}

\author{
Effect of the Experimental Introduction of the Daily Brief Report Teaching Method \\ and Students' Characteristics
}

\section{小貫 睦巳 ${ }^{1)}$}

\author{
MUTSUMI ONUKI ${ }^{1)}$ \\ 1) Department of Physical Therapy, Faculty of Health Science, Tokoha University: 1230 Miyakoda-cho, Kita-ku, Hamamatsu-shi, \\ Shizuoka431-2102, Japan.TEL+81 53-428-1219E-mail:monuki@hm.tokoha-u.ac.jp
}

Rigakuryoho Kagaku 29(5): 671-677, 2014. Submitted Mar. 3, 2014. Accepted Apr. 23, 2014.

\begin{abstract}
Purpose] We introduced the daily brief report (DBR) method, a teaching method focusing on learners, to physical therapy lectures, and investigated the effect of the method and the characteristics of the students. [Subjects and Methods] Based on the results of a questionnaire administered to 43 university students and 56 vocational training school students attending the classes, we compared the results with the data of Uta, performed categorical principal component analysis, and analyzed them using the text mining method. [Results] Compared with conventional group education, more than half of the physical therapy students perceived the DBR method positively, and we found that they held a sense of wanting to learn by themselves. [Conclusion] Our results suggest that it is possible to raise students' motivation levels by introducing the DBR method into lecture classes, and through making students write reports every time, it can be said that the DBR method has the advantages of individually raising students' motivation to learn and correcting their mistakes which is absent from conventional group education.
\end{abstract}

Key words: daily brief report teaching method, active learning, physical therapy education

要旨：〔目的〕学習者主体の授業方法である当日ブリーフレポート方式授業を理学療法の講義形式の授業に取り入れ, 教育手法の効果と現代の理学療法学生の特性を検証した。〔方法〕授業に参加した大学生 43 名, 専門学校生 56 名の アンケート結果を基に宇田のデータと比較し，カテゴリカル主成分分析，テキストマイニングの手法を用い分析した 〔結果〕従来型の一斉授業と比べ, この方式の授業は理学療法学生の過半数が肯定的に捉えており, 理学療法学生は 真面目で自ら学ぼうという意識を持っているという特性が見られた。〔結語〕毎回のレポート課題を通して学生に働 きかける事により，個々に学習意欲の喚起や間違いの修正が可能な点は従来型の一斉授業にない利点といえ，講義形 式の授業に取り入れる事で学生の動機付けを高める事が可能である事が示された.

キーワード : 当日ブリーフレポート方式授業, Active-Learning, 理学療法教育

1) 常葉大学 保健医療学部 理学療法学科: 静岡県浜松市北区都田町 1230 (

受付日 2014 年 3 月 3 日 受理日 2014 年 4 月 23 日 


\section{I.はじめに}

理学療法教育ガイドライン 1)にあるように，教授方 法には様々な形態のものがあり，技術習得に重きを置い た理学療法教育では, 少人数のグループ学習で, 実習· 演習形式の授業が昔から行われてきた。しかし大学での 講義形式の授業では，いまた座学中心の従来型講義が多 勢を占めていると考えられる。従来型の一斉学習指導は 大量の知識を一度に均等に提供できるという点では効率 的で優れているものの, 学習者の特性に個人差の大きい 昨今の教育環境では主体的に学ぶ意欲の育成や学習者の ペースに応じた習熟には限界があると言われている2). そうしたなか, 一斉学習指導でない学習者主体の授業方 法 (active-learning) が多く開発されてきている.

このような学習者主体の授業方法の一つに, 当日ブ リーフレポート方式 (brief report of the day: 以下 BRD) 授業がある。これは宇田によって 2005 年に発表された 授業手法であり, 毎回の授業の最後に小レポートを課し (1)テーマ確認, (2)構想段階, (3)情報収集段階, (4)執筆段 階，という手順で授業を進めるものである。また BRD 授業のねらいとして, (1)課題の明示, (2)個別化, (3)双方 向性, (4)私語の抑制効果, (5)出席の促進効果, (6)授業の 分節化, (7)文章力の養成, (8)実用性, が挙げられる3)（表 1)。学生一人ひとりが制限時間内に課題に取り組み，小 テスト形式のレポートを毎回提出する事で授業にメリハ リをつける。また，提出物をポートフォリオとして扱う 事で, 形成的評価や内発的な動機付けを高めるものであ る. 教員は毎回の採点業務が大変ではあるが, その短所 を補ってあまりある効果があると言われている。

また, 現代の医療系の専門職養成機関の学生気質とし て, (1)意欲·主体性のなさ，(2)表面的な真面目さ，(3)要 求の厳しい依存性, (4)打たれ弱さ, などが挙げられる4). 看護教育に沶いては，柳川ら5)によると，現代の看護 学生のほうが(1勉強ぶりはよく, 課題に辛抱強く取り組 む学生が増加している。，一方，(2)行動力を持って自ら取 り組み確かめながら学んでいく学生は減少, (3)授業中の 私語は 1987 年に $22 \%$ だったのが 2009 年には $79 \%$ と著
明に増加, (4)他人に対して寛大な学生が増えているが, 自ら話しかける社交性は低下している。歯科衛生士の学 生気質もほぼ同様の結果となっている6)。理学療法教育 に执いては，(1)知識量の多い学生が増えたが問題の認識 力や問題解決能力がそしい, (2)人間関倸作りも学生同士 であっても双方向の会話が出来る関係を築くのが不得手 になってきているなど, 看護教育と同様の問題点が挙げ られている7)。高木はこれらの問題は「ゆとり教育」な どの教育システムや少子化社会が大きく影響していると 述べており，教員はこれらを踏まえた上で時代とともに 変化する学生の価值観や行動様式を理解して, 教育目標 に到達する手だてを考えなければいけない，

このような問題に対応するべく, 英米の医学教育では 「自己主導型学習」や「省察的実践」が早くから用いられ, PBLチュートリアルやOSCEのように実践的な教育手 法へと進化してきている，我が国の医学教育でもこれを 後追いする形で, 学生が受身でなく能動的な態度で学習 が進めら机る方向へ変わってきている ${ }^{8)}$. しかしながら, 理学療法教育ではこれらの実践的教育手法はまだ端緒に ついたばかりであり，学習者主体の授業方法も演習形式 の授業を中心に少しずつ取り入れられてきているょうで あるが, 理学療法学生の学生気質の調査を含め, 具体的 に実践を行った研究は少ない.

本研究はこの BRD 授業を理学療法の講義形式の授業 で用い，一斉学習指導の欠点を補い，従来の方式と比心゙ どのような利点があるのかを調査し, 学習者主体の教育 手法の効果について明らかにする。 また学生のアンケー 卜結果から現代の理学療法学生の特性を分析し, 今後の 学生指導や授業の工夫に必要な情報を明らかにする事を 目的とする。

\section{II. 対象と方法}

対象は $\mathrm{A}$ 大学と $\mathrm{B}$ 専門学校（四年制）の理学療法学 科 2 年生とし, 講義形式の専門教育科目の 15 回の講義 のうち 10 回, BRD 授業を行った。 その際, 開講時のガ イダンスで授業の進め方を十分説明し, 各授業の最後に

表 1 BRD 授業のねらい

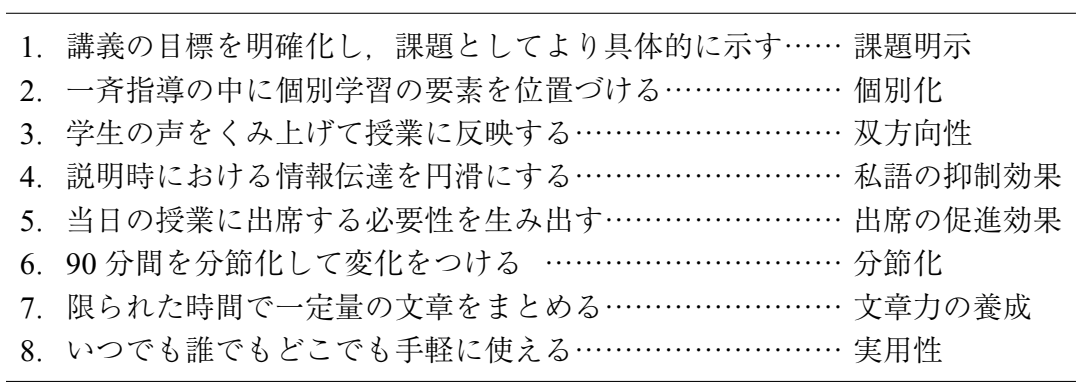

文献 ${ }^{3)}$ より改変 
行う 10 回の小テストの結果も成績評定の一部に含まれ る事を伝え，理解が得られた事を確認して開始した。 BRD 授業については宇田の方式に則り，前述の 8 つの ねらいに基づいて毎回を以下の手順で行った。すなわち 1. 授業の最初に本日のテーマを確認する, 2. テーマ について構想段階・情報収集段階を設ける，3．授業の 最後に小テスト形式のレポートの執筆段階を設ける, で ある、レポートのテーマについては出来るだけ客観的な 回答を得られるものを多く選んだ，採点は絶対評価で採 点し, 個々の学生の良い点を認め, 自己効力感を高める ように配慮した。また，これらはすべて開講前に準備し た。

15 回の授業終了時にアンケート調査を行った。アン ケートは無記名とし, 集合調査法にて行った。 アンケー 卜内容はまずBRD 授業の満足度と集中度をそれぞれ $\lceil 1$. 非常に低い」，「2．低い」，「3．どちらとも言えない」, 「4. 高い」, 「5. 非常に高い」の 5 段階の順序尺度で確 認した。次に従来の講義形式の授業と BRD 授業のどち らが良いかを「1. 従来の講義形式」,「2. どちらも変わ らない」，「3. BRD 方式」の3 段階の順序尺度で確認し た。ささに，なぜそれを選んだのかを自由記載で回答し てもらった。 また, BRD 授業の特性として, 宇田が教 育心理学の授業で用いた BRD 授業の感想アンケートの 項目である，(1)授業に変化がある，(2)期末テストのみで 成績が決まらない, (3)知識の丸暗記でなく文章力がつく (4)授業の目標が明確である，(5)授業中私語が少ない，(6) 授業に緊張感がある，の6 項目を宇田の方式と同様に 3 段階の順序尺度で確認した。最後にBRD 方式授業の長 所と短所を自由記載で回答してもらった。

これらのアンケート結果の解析には, カイ二乗独立性 の検定を行い宇田のデータと本研究のデータを比較し, また大学と専門学校間の違いも検討した。ささらに, カテ ゴリカル主成分分析を行い, カテゴリーの数量化と成分 負荷を算出し大学と専門学校の特徵を掴み, それぞれの 学生の特性を検討した。統計処理にはIBM SPSS Statistics ver.22 を使用し有意水準は $5 \%$ とした。

アンケートの自由記載の項目については Berelsonの 提唱した内容分析の手法を参考にし，テキストマイニン グの手法を用いた．形態素解析システム「茶笔」を用い てテキストデータをキーワード化し, その出現頻度をヒ ストグラムで表示した。 その際, 同意味を持つキーワー ドについては，客観的になるよう意味内容に注意して キーワード化を行った。 また, 先のカテゴリカル主成分 分析の結果と比較し, 分類し構造化を行った。

なお, 今回の研究にあたり, 学生には研究の主旨を十 分説明し, アンケートの結果は本研究以外には使用しな い事, 本研究に参加しなくても成績や指導での不利益に はならない事, およびデー夕は厳重に管理し研究終了後 は直ちに適切な方法でデー夕を消去する事を文書に明記
し，口頭にて説明した。 アンケートの提出を持って同意 とみなした。また，本研究は本学研究倫理委員会の承認 を受けて行った（承認番号 2013-002H）.

\section{III. 結果}

BRD 授業に参加した学生は, A 大学が 43 名（男性 29 名, 女性 14 名, 平均年齢 $19.4 \pm 0.4$ 歳), B 専門学 校が 56 名（男性 43 名, 女性 13 名, 平均年齢 $21.7 \pm 3.9$ 歳）であった。 10 回の BRD 授業のテーマと大学, 専門 学校の平均点を表 2 に示す. BRD 授業の満足度と集中 度については A 大学と B 専門学校の間ではいずれも差 は見られず，両方とも「4. 高い」と「5.非常に高い」 を併せて過半数であった（表 3)。またこの結果は，宇 田の結果とほぼ同様の比率であった ${ }^{9)}$. しかし従来の講 義と BRD 授業とどちらが良いかについては, 宇田の結 果と A大学の間に, また A大学と B 専門学校の間に, 「2. どちらも変わらない」が $\mathrm{A}$ 大学のほうに多いという結 果となり，両方ともに有意差がみられた（いずれも $\mathrm{p}<0.05$ 表 4). さらに男女別に分けて様々な検討をし た結果，A 大学の男子学生が従来の講義形式と BRD 方 式とどちらが良いかについて態度を保留し，「2，どちら も変わらない」を選択していることが特徴的であった。

次に BRD 授業の特性 6 項目の内訳について, A 大学 では(2)〜 (4)の 3 項目が「はい」が過半数, B 専門学校で は(1)〜 (4)の 4 項目が「はい」が過半数であった. (5)と (6) については A 大学も B 専門学校も (1)〜 (4)と比べ「どち らでもない」,「いいえ」の比率が高かった（表 5). 特 にA大学の方にその傾向が著明であった.

カテゴリカル主成分分析の結果については, 成分負荷 は3つの主成分に分けられ，A大学では第 1 主成分は「満 足度」,「集中度」,「授業に変化がある」,「目標が明確」, 「期末テストのみで決まらない」が挙げられ，第 2 主成 分は「私語が少ない」, 「緊張感有り」, 第 3 主成分は「丸 暗記でなく文章力がつく」が挙げられた，B 専門学校で は第 1 主成分が $\mathrm{A}$ 大学と同様の項目が挙げられたのに 加え, A 大学の第 2 主成分である「私語が少ない」,「緊 張感有り」の二つの項目も第 1 主成分に含まれる結果と なった。第 2 主成分は「期末テストのみで決まらない」 であり，第 3 主成分は A 大学と同じ「丸暗記でなく文 章力がつく」が挙げられた（表 6).

アンケートの BRD 方式授業の長所についての自由記 載であるが, A 大学は 46 項目, B 専門学校は 56 項目 の回答が得られた（複数回答・重複回答含む）。同様に 短所についての自由記載は A 大学が 27 項目, B 専門学 校は 36 項目であった。長所の自由記載について，茶笔 の形態素解析により品詞情報を基にキーワードを取り出 し分類した結果，「疑問点などを直接先生に訴える事が 出来る」，「自分から調べるようになる」などの【自発的 
表 2 BRD 授業のテーマ

\begin{tabular}{|c|c|c|c|c|}
\hline 回 & A 大学 & 平均点 & $B$ 専門学校 & 平均点 \\
\hline 1 & $\begin{array}{l}\text { リハビリテーションとはなにか. 今回の授業 } \\
\text { で触れたことだけでなく, 今まで習ったこと } \\
\text { を踏まえてまとめなさい. }\end{array}$ & 73 & $\begin{array}{l}\text { ボディメカニクスを考えるときに, 「てこ」を } \\
\text { 使ってどのように介助やハンドリングに活か } \\
\text { せば良いか, てこの例を挙げてまとめなさい. }\end{array}$ & 75 \\
\hline 2 & $\begin{array}{l}\text { リハビリテーション前置主義とはなにか. 地 } \\
\text { 域リハビリテーションにおいてどのような意 } \\
\text { 味があるのか, 説明しなさい. }\end{array}$ & 82 & $\begin{array}{l}\text { ROM 訓練を行う上でのポイントを整理して挙 } \\
\text { げ, 説明しなさい. }\end{array}$ & 84 \\
\hline 3 & $\begin{array}{l}\text { ICIDH から ICF に変わった経緯に基づき, ICF } \\
\text { を説明しなさい. }\end{array}$ & 72 & $\begin{array}{l}\text { 日常生活の中における遠心性収縮（伸張性収 } \\
\text { 縮）の例を挙げ, どの筋が収縮するのかを含 } \\
\text { め説明しなさい. }\end{array}$ & 75 \\
\hline 4 & $\begin{array}{l}\text { 地域理学療法を行う (1)対象者・(2)関連制度に } \\
\text { ついて説明しなさい. }\end{array}$ & 72 & $\begin{array}{l}\text { 至適運動強度について, 廃用と過用との関係 } \\
\text { から述べよ. また, 特に高齢者に運動負荷試 } \\
\text { 験等を行う場合に注意しなければならないこ } \\
\text { とを挙げなさい. }\end{array}$ & 64 \\
\hline 5 & $\begin{array}{l}\text { 呼吸の (1)生理学的特徵, (2)解剖学的特徵につ } \\
\text { いてまとめなさい. }\end{array}$ & 64 & $\begin{array}{l}\text { 配付資料の p59 の設問 1-3 に答えよ.（最大酸 } \\
\text { 素摂取量を擬似測定する演習の後に出題. 運 } \\
\text { 動生理の問題) }\end{array}$ & 48 \\
\hline 6 & $\begin{array}{l}\text { なぜ, (1)裖瘡が生じるのか, その理由と(2)裖 } \\
\text { 瘡を予防するにはどのような対策が必要かに } \\
\text { ついて述べよ. }\end{array}$ & 64 & $\begin{array}{l}\text { ボルグスケールは順序尺度である. これ以外 } \\
\text { に，4つの尺度の例をそれぞれ挙げて違いを説 } \\
\text { 明しなさい. }\end{array}$ & 85 \\
\hline 7 & $\begin{array}{l}\text { 地域において(1)理学療法士が行うべき健康状 } \\
\text { 態の評価にはどのようなものがあるか, (2)ま } \\
\text { たそのうちのひとつを説明しなさい. }\end{array}$ & 84 & $\begin{array}{l}\text { FR，TUG をそれぞれ文章化してまとめなさい. } \\
\text { BRD 用紙の左にFR }, \text { 右に TUG を書くよう } \\
\text { に. }\end{array}$ & 78 \\
\hline 8 & $\begin{array}{l}\text { 暮らしやすい家 (住環境) とは何か. 説明し } \\
\text { なさい. }\end{array}$ & 68 & $\begin{array}{l}\text { 第 } 7 \text { 回で学んだFR.TUG, そして今回の FBS } \\
\text { で調べようとしている「バランス障害」とは } \\
\text { 何かをまとめなさい. }\end{array}$ & 76 \\
\hline 9 & $\begin{array}{l}\text { 福祉用具の導入において理学療法士が注意し } \\
\text { ておかなければいけないことは何か. 具体例 } \\
\text { を挙げて説明しなさい. }\end{array}$ & 67 & $\begin{array}{l}\text { 6MD， } 10 \mathrm{~m} \text { 歩行をそれぞれ文章化してまとめ } \\
\text { なさい. BRD 用紙の左に } 6 \mathrm{MD} \text { を，右に } 10 \mathrm{~m} \\
\text { 歩行を書くように. }\end{array}$ & 89 \\
\hline 10 & $\begin{array}{l}\text { 尊厳あるケアとはどういうものか.「ぴんぴん } \\
\text { ころり」の話からあなたの考えを述べよ. }\end{array}$ & 93 & PCI の利点と欠点を考察しなさい. & 80 \\
\hline
\end{tabular}

表 $3 \mathrm{BRD}$ 授業の満足度 $\cdot$ 集中度

満足度

\begin{tabular}{lccccc}
\hline 対象学校 & $\begin{array}{c}\text { 非常に低い } \\
(\text { 名 })\end{array}$ & $\begin{array}{c}\text { 低い } \\
(\text { 名 })\end{array}$ & $\begin{array}{c}\text { どちらとも言えない } \\
(\text { 名 })\end{array}$ & $\begin{array}{c}\text { 高い } \\
(\text { 名 })\end{array}$ & $\begin{array}{c}\text { 非常に高い } \\
(\text { 名 })\end{array}$ \\
\hline A 大学 & 1 & 2 & 15 & 23 & 2 \\
B 専門学校 & 0 & 6 & 17 & 28 & 5 \\
\hline 集中度 & & & & & \\
\hline 対象学校 & 非常に低い & 低い & どちらとも言えない & 高い & 非常に高い \\
\hline A 大学 & $($ 名 & $($ 名 $)$ & $($ 名 $)$ & $($ 名 $)$ & $($ 名) \\
B 専門学校 & 1 & 3 & 12 & 22 & 5 \\
\hline
\end{tabular}


表 4 従来の講義形式と BRD 授業とどちらがよいか

\begin{tabular}{|c|c|c|c|c|}
\hline 対象学校 & $\begin{array}{c}\text { 従来の講義形式 } \\
\text { (名) }\end{array}$ & $\begin{array}{c}\text { どちらも変わらない } \\
\text { (名) }\end{array}$ & $\begin{array}{l}\mathrm{BRD} \text { 方式 } \\
\text { (名) }\end{array}$ & \\
\hline A 大学 & 4 & 17 & $7 * 7$ & \\
\hline B 専門学校 & 7 & 15 & ]$^{*}$ & $*$ \\
\hline C 宇田の結果 & 8 & 9 & 41 & \\
\hline
\end{tabular}

$* \mathrm{p}<0.05$

表 5 BRD 授業の特性 6 項目の内訳

A 大学

\begin{tabular}{lccc}
\hline \multicolumn{1}{c}{ 項目 } & はい $($ 名 $)$ & どちらともいえない $($ 名) & いいえ (名) \\
\hline (1)授業に変化がある & 16 & 21 & 6 \\
(2)期末テストのみで成績が決まらない & 28 & 9 & 5 \\
(3)知識の丸暗記でなく文章力がつく & 22 & 17 & 4 \\
(4)授業の目標が明確である & 22 & 17 & 4 \\
(5)授業中私語が少ない & 10 & 22 & 11 \\
(6授業に緊張感がある & 3 & 28 & 12 \\
\hline
\end{tabular}

$\mathrm{B}$ 専門学校

\begin{tabular}{lccc}
\hline \multicolumn{1}{c}{ 項目 } & はい $($ 名 $)$ & どちらともいえない (名) & いいえ（名） \\
\hline (1)授業に変化がある & 33 & 21 & 2 \\
(2)期末テストのみで成績が決まらない & 41 & 13 & 2 \\
(3)知識の丸暗記でなく文章力がつく & 47 & 8 & 1 \\
(4)授業の目標が明確である & 45 & 9 & 2 \\
(5)授業中私語が少ない & 24 & 25 & 7 \\
(6)授業に緊張感がある & 16 & 33 & 7 \\
\hline
\end{tabular}

に学ぶ】「授業に集中できる」，「集中的に講義を聞く事 が出来る」などの【集中できる】，「書く力が向上する」, 「文章をまとめる力がつく」などの【文章力のトレーニ ング】,「レポートが成績に反映される」,「出席が大切に なる」などの【期末テストのみで決まらない】, それ以 外の【その他】の 5 項目に分類できた（表 7).

\section{IV. 考察}

BRD 授業については, 全体として宇田の結果と同じ ように，大学も専門学校も一方向的な座学を中心とした 従来型の授業よりも満足度·集中度ともに高く, 学生の 過半数が肯定的に捉えていることがわかった。自由記載 の数・内容を見てもそれが表れており，BRD 授業の学生 の受け容れは概ね良好であると言える。一方, 宇田の結 果や B 専門学校の結果と比べ A 大学の男子学生が BRD 授業も従来方式も「どちらも変わらない」とした理由に ついては不明であるが, 対象者数が少ない事や大学の男 子学生には専門学校や大学の女子学生と比べた場合の何 らかの特性が関係している可能性が考えられる。この点 については今後引き続き検証していく必要がある.
BRD 授業の特性 6 項目の結果については，(5)授業中 の私語と6緊張感は他と比べて感覚的な要素であり，ま た環境に依存する要素でもある。これらは従来型の授業 と比較してそれと差が見いだせる BRD 授業の明らかな 特徴と言いにくく，この点から「どちらともいえない」 「いいえ」の比率が高くなった可能性が考えられる。 ま た柳川の主張にある現代学生の私語の増加も影響してい るかもしれない. この点については今後もこの方式を続 けていく事で見極めていきたいと考えている.

またカテゴリカル主成分分析の結果は，第 1 主成分で 「集中度」や「授業に变化がある」，「授業の目標が明確」 のように学生自身の内面から学びの意欲が表れるといえ る内的因子が強く働いている（A 大学, B 専門学校とも に寄与率 44\%）と捉えることができる。一方，第 1 主 成分ほどではないが，A 大学の第 2 主成分にある「授業 中の私語」,「授業の緊張感」のように環境面に依存した 外的因子も一部関係している（寄与率 17\%）といえる. $\mathrm{A}$ 大学, $\mathrm{B}$ 専門学校ともに第 3 主成分となった「知識の 丸暗記でなく文章力がつく」(寄与率は A 大学 $14 \%, B$ 専門学校 $15 \%$ ）は, BRD授業の大きな特徵であるレポー 卜課題付与による文章力の養成がそのまま表れているも 
表 6 カテゴリカル主成分分析の成分負荷

A 大学

\begin{tabular}{lrrr}
\hline & \multicolumn{3}{c}{} \\
& 第 1 主成分 & $\begin{array}{c}\text { 次元 } \\
\text { 第2 }\end{array}$ 主成分 & 第 3 主成分 \\
\hline 満足度 & 0.803 & 0.459 & 0.312 \\
集中度 & 0.802 & 0.466 & 0.299 \\
授業に変化がある & 0.633 & -0.114 & -0.027 \\
期末テストのみで成績が決まらない & 0.727 & -0.269 & -0.216 \\
知識の丸暗記でなく文章力がつく & -0.327 & -0.158 & 0.873 \\
授業の目標が明確である & 0.644 & 0.336 & -0.226 \\
授業中私語が少ない & 0.621 & -0.564 & -0.046 \\
授業に緊張感がある & 0.603 & -0.651 & 0.239 \\
\hline
\end{tabular}

$B$ 専門学校

次元

第 1 主成分 第 2 主成分 第 3 主成分

\begin{tabular}{l|rrr}
\hline 満足度 & 0.687 & 0.590 & -0.150 \\
集中度 & 0.838 & 0.218 & -0.200 \\
\hline 授業に変化がある & 0.891 & 0.114 & -0.113 \\
期末テストのみで成績が決まらない & 0.046 & 0.759 & 0.434 \\
知識の丸暗記でなく文章力がつく & -0.010 & -0.018 & 0.900 \\
授業の目標が明確である & 0.716 & -0.239 & 0.108 \\
授業中私語が少ない & 0.726 & -0.386 & 0.112 \\
授業に緊張感がある & 0.742 & -0.368 & 0.239 \\
\hline
\end{tabular}

注：分類された成分ごとに網掛けを行った

表 7 アンケート自由記載 BRD 授業の長所のキーワード分類

\begin{tabular}{|c|c|c|}
\hline キーワード & A 大学 & B 専門学校 \\
\hline 自発的に学ぶ & $\begin{array}{l}\text { 疑問点などを直接先生に訴える事が出来る, } \\
\text { 自分の考えを持てる など }\end{array}$ & $\begin{array}{l}\text { 自分で考える事が出来るので理解が深まる, } \\
\text { 自分から調べるようになる など } \quad \text { 計 } 29 \text { 個 }\end{array}$ \\
\hline 集中できる & 授業に集中できるなど＼cjkstart計 14 個 & 集中的に講義を聞く事が出来るなど＼cjkstart計 7 個 \\
\hline $\begin{array}{l}\text { 文章力のトレー } \\
\text { ニング }\end{array}$ & $\begin{array}{l}\text { 文章の組み立ての練習になる, } \\
\text { 文章をまとめる力がつく など }\end{array}$ & $\begin{array}{l}\text { レポートの練習になる，書く力が向上する など } \\
\text { 計 } 17 \text { 個 }\end{array}$ \\
\hline $\begin{array}{l}\text { 期末テストのみ } \\
\text { で決まらない }\end{array}$ & 出席が大切になる & レポートが成績に反映される \\
\hline その他 & & いい点が取れると気分がよく，勉強が好きになれる \\
\hline
\end{tabular}

のと考えられる。これらの結果から, 現代の理学療法学 生は, (外的環境から影響を受けるよりも) 自身の内面 に目を向ける傾向が強いという事が示唆される.

アンケートの自由記載の結果からは, BRD 授業の長

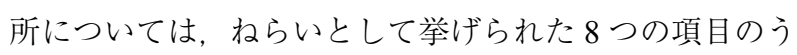
ち, (1)課題の明示, (2)個別化, (3)双方向性, (6)授業の分 節化の 4 つは自由記載の表現として明確に区別しにく く、これらを【自発的に学ぶ】してひとつのカテゴ リーとして扱った。 (5)出席の促進効果は【期末テストの みで決まらない】に該当し，(7)の文章力の養成は文字通
り【文章力のトレーニング】に該当する。この結果より BRD 授業の長所の自由記載の結果もカテゴリカル主成 分分析と同様の結果を表していると考えられる. 敷地 ら 10)によると理学療法学生の学習動機形態については, 学習動機として実用志向が強く, 内発的な動機付けが強 い傾向を示したとある。今回の結果もそれと同様の結果 であり, 現代の理学療法学生は, 概ね真面目で自ら学ぼ うという意識は持っているものと考えられる。

京都大学高等教育研究開発推進センターらの『大学生 のキャリア意識調査 2007』11)によると, 医療系の学生 
は他の文系や理系の学生よりも職業・進路選択について 理解し, 納得している比率が他学部の 2 倍近く高い. こ の理由として医療系の学生の場合は入学時にすでに職業 選択が決まっており，そのことが真面目に学ぼうという 意識の表れになっていると考えられる.

教育研究者の溝上によると, 大学生の学業の動機付け は彼らの大学生活や社会環境と密接に関係しており, 学 生自身の過去の経験や成果, 将来への見通しなどとの結 合関係によって大きく影響を受ける ${ }^{12)}$. 同時に最近の 学生は, 大学生活が多次元にわたり忙しいものとなって きており，授業に繁く出席するとともにクラブやサーク ル活動，アルバイトに余念がないとも言っている ${ }^{13)}$. その上で溝上は, 成人として未熟な若者は感情と認識が 別物であり，そのような心理的な特性を踏まえた上での 授業の必要性を説いている。真面目に学ぶ意識の高いと いう医療系の学生といえども，このことを踏まえて個々 の学生指導に活かしていく必要がある.

本研究より, 現代の理学療法学生の学習動機における 特性は, 真面目で自ら学ぼうという意識を持っている事 であり，BRD 授業という学習者主体の授業手法につい て受け容れも良いという事が示された。また実際に BRD 授業は毎回のレポート課題を通して個々の学生の 思考や文章力を把握でき, ある程度きめ細かな授業の フィードバックが可能である。 また, 講義形式の授業で ありながら双方向性の指導が可能である事に特徴があり 毎回のレポート課題を通して学生に働きかける事により 学生の動機付けを高め, 学生個々に学習意欲の喚起や, 間違いの修正が可能な点は従来の講義形式にない利点と 言える。学生の学習意欲をはじめとした個人差が大きく なっていると言われる昨今においては, BRD 授業のよ うに学生の自発性を促し, 双方向性を確保できる手法で の授業展開は，医療系の学生には極めて有効であると考 えられる. BRD 授業の短所としては, 毎回のレポート の採点や授業の準備に手間がかかる事であるが，この点 はテーマを工夫し, 授業の進め方のスキルを高める事で 解消していけるものと考えられる。また 活用する事で教員の事務的な手間を減らしていく事も可
能であろう.

今後は，このBRD 授業を基に，理学療法学生に特化 した授業手法を開発し，学習者が意欲を高められるよう な質の高い授業を提供できるように研鑽を積んでいきた いと考えている。

謝辞 本研究に対し，アンケートにご協力いただいた養 成校の学生の皆様に深く感謝申し上げます.

\section{引用文献}

1) 公益社団法人日本理学療法士協会 : 理学療法教育ガイドラ イン. https://www.japanpt.or.jp/jpta/gl/guidelines.html（閲覧 日 2014 年 2 月 13 日).

2) 久保田まり：教育心理学. 理学療法学教育論. 奈良勲編, 医歯薬出版, 東京, 2004, pp25-29.

3) 宇田 光: 大学講義の改革 BRD (当日レポート方式)の提 案. 北大路書房, 東京, 2005, pp28-29.

4) 高木邦子：現代の学生気質とその対応. OTジャーナル, 2011, 45: 320-325.

5) 柳川育子, 矢吹明子：現代の看護学生の生活及び気質の特 徵 (第 1 報) - 2009 年と 2000 年及び 1987 年との比較一. 京 都市立看護短期大学紀要. 2010, 35: 197-211.

6) 山田隆文：歯科衛生士学科の学生気質と教育課題. 明倫歯 科保健技工学雑誌, 2006, 9: 87-89.

7) 高村雅二, 彦田龍兵・他：[座談会] 臨床実習の問題解決に 向けて. PTジャーナル, 34(3): 153-169.

8) 大西弘高：新医学教育学入門. 医学書院, 東京, 2005 , pp66-71.

9) 宇田 光：大学講義の改革 BRD (当日レポート方式)の提 案. 北大路書房, 東京, 2005, pp48-54.

10) 敷地雄一, 宮本省三, 森岡 周 - 他: 理学療法学科学生の 学習動機に関する研究一学習動機の形態及び学業成績との 関連性一. 理学療法学, 1999, 26: 163-167.

11) 京都大学高等教育研究開発推進センター, 電通育英会 : 大 学生のキャリア意識調査 2007. http://www.dentsu-ikueikai. or.jp/research/top.html (閲覧日 2014年2月 13 日).

12) 溝上慎一: 大学教育学. 培風館, 東京, 2005, pp124-125.

13) 溝上慎一：現代大学生論一ユニバーシティ・ブルーの風に摇 れる一. 日本放送出版協会, 東京, 2004, pp177-180. 